\title{
Having a bad attitude? The relationship between attitudes and sickness absence
}

\author{
Karen Evelyn Hauge ${ }^{* \dagger}$ (D) and Marte Eline Ulvestad ${ }^{\dagger}$
}

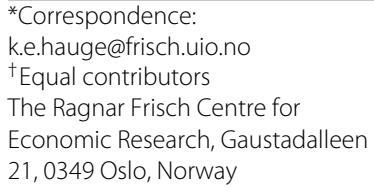

21, 0349 Oslo, Norway

\begin{abstract}
Is sickness absence related to attitudes? Several studies point to attitudes as an important factor for sickness absence. We study the relation between sickness absence and attitudes towards possible reasons for sick leave, towards cheating and towards work, by linking a survey among Norwegian healthcare workers, aimed at identifying attitudes, to detailed data on sickness absence from the employers. We find that there is an association between sickness absence and certain attitudes but mainly for self-certified sick leave. Employees with more lenient attitudes towards sick leave have more self-certified sick leave, but not more GP-certified sick leave. Furthermore, we find no evidence of attitudes being able to explain the persistently observed differences is absenteeism between different demographic groups.
\end{abstract}

JEL Classification: 11, 112, J01, J45

Keywords: Norway, Sickness absence, Attitudes, Absenteeism, Demographic groups, Gender, Survey, Healthcare sector

\section{Introduction}

Paid sick leave and sickness benefits are central parts of the social security systems of the European welfare states. The first preliminary outline of a European pillar of social rights states that, "All workers, regardless of contract type, shall be ensured adequately paid sick leave during periods of illness" (European Commission 2016a, 13). Sick pay and sickness benefits are important as protection of an employee's income during periods of illness or injury. Without this financial insurance, employees that cannot afford the loss of income might be forced to work while sick. This can further deteriorate the employee's health and might also have other unfortunate consequences, such as the spreading of disease and lower firm productivity (Scheil-Adlung and Sandner 2010; Hemp 2004; Hansen and Andersen 2008).

The entitlement to sick leave, sick pay and sickness benefits, and the duration and replacement level of the compensations, vary considerably between the welfare states. Nevertheless, all the EU member countries provide rights to sick leave and to sickness benefits and most of them also to paid sick leave. Sick leave is the right to be absent from work, while paid sick leave is the payment of (part of) the employee's salary by the employer during sickness. Sickness benefits are covered by the social protection system (Spasova et al. 2016).

(C) The Author(s). 2017 Open Access This article is distributed under the terms of the Creative Commons Attribution 4.0 International License (http://creativecommons.org/licenses/by/4.0/), which permits unrestricted use, distribution, and reproduction in any medium, provided you give appropriate credit to the original author(s) and the source, provide a link to the Creative Commons license, and indicate if changes were made. 
The OECD countries spend on average around $0.8 \%$ of GDP on sickness benefits alone (OECD 2010, 58). In Norway, where the sickness benefit scheme is particularly generous, around 1.6-1.7\% of GDP is allocated to sickness benefits annually (Bjørnstad 2013, 22). How these spendings can be reduced, or whether these spendings can be utilised in a better way, is currently being debated, both in Norway and in other developed countries (OECD 2010).

While the necessity for short-term sick leave is often based on the employee's own assessment, long-term sick leave is usually certified by a general practitioner. But whether an employee actually seeks medical help is usually dependent on the employee's own initiative. This means that the employee's sick leave might be influenced by own health assessment and the employee's opinion of when sick leave is needed. Additionally, this implies that the sickness benefit schemes depend on trust in the employees and their assessments.

Several studies have pointed to attitudes as an important factor for sickness absence. For instance, Dale-Olsen and Markussen (2010), who have studied trends in absenteeism over time for specific diagnoses, find that the number of sickness absence spells due to specific diagnoses has not changed much over time, but that the duration of each spell has increased by $20 \%$ in the period under study (1972-2008). The authors point to changing demands from employers and changing attitudes to explain why it would take longer to heal a broken leg in 2008 compared to in 1972.

Henrekson and Persson (2004) find that increases in the generosity of sickness insurance benefits tend to be associated with more permanent sick leave. Also, Askildsen et al. (2005) show that the often seen negative correlation between sickness absence and unemployment rates are mainly caused by established workers changing their behaviour, rather than by the composition of the labour force. The fact that employees seem to exercise some flexibility in their absence behaviour opens up the possibility that attitudes might be a part of the explanation for variation in sickness absence.

Although several studies have pointed to attitudes as an important factor for sickness absence, few studies address this relationship directly (Allebeck and Mastekaasa 2004). Holmås and et al (2008) study attitudes towards sickness absence in the Nordic countries, but do not study the relation between attitudes and absence behaviour. Hansen and Andersen (2008) analyse the relationship between attitudes and sickness presence (going to work while sick). Their measure of sickness presence, as well as sickness absence, is, however, based on self-reported data. A weakness with using self-reported data on absence is the possibility of misreporting, unconsciously or consciously, due to either not recalling correctly or a desire to present oneself in a positive way.

Furthermore, most studies on sickness absence within economics rely on data concerning general practitioner (GP)-certified or long-term sickness absence, as Nationwide registers often are available for GP-certified or long-term sickness absence (where the employee is eligible for sickness benefits). Register data is an objective and reliable data source, but does not include self-certified sickness absence nor information about attitudes. This study is the first, to our knowledge, to use actual sickness absence data as opposed to self-reported data, for both self-certified and GP-certified sickness absence, and to match this with data on individual attitudes. Our study therefore contributes to the literature on sickness absence by studying the relationship between attitudes and sickness absence empirically and by using objective, employer-registered data on both 
self-certified and GP-certified sickness absence. Our study includes attitudes towards possible reasons for sick leave, towards cheating and towards work.

Understanding the mechanisms behind sickness absence is important for several reasons. First of all, a possible relationship between attitudes and sickness absence is interesting in its own right. Secondly, the sickness insurance system takes for granted that self-certified sick leave is claimed by, and sick leave certified by a GP is provided to, people with reduced work capacity and that this measure of work capacity can be determined fairly objectively. However, if it turns out that individual attitudes towards sick leave are related to actual sickness absence behaviour, this might indicate that the term "reduced work capacity" is perceived differently and that it is, to some extent, a subjective perception that determines whether an individual is entitled to sickness insurance.

Furthermore, it is important to utilise the welfare state's resources effectively, as sickness benefits constitute a significant share of developed countries' spendings. An important precondition for reducing sickness absence, and thereby its costs, is to understand the underlying mechanisms.

In this study, we analyse whether and to what extent sickness absence is related to attitudes. To investigate this matter, we have collected data from two different sources. A survey, aimed at identifying relevant attitudes, has been conducted among employees within public healthcare in the city of Oslo, Norway. Additionally, detailed data on sickness absence for the respondents was assembled from the employers. By linking these two data sources, we obtain information on the actual absence behaviour, together with subjective assessments.

The public healthcare sector, which is the largest sector within the public sector in Norway, comprises around half of all full-time equivalents in the public sector (GranHenriksen 2014). Furthermore, the public healthcare sector has a particularly high rate of sickness absence compared to other sectors in Norway. The average sick leave rate for all sectors in Norway in 2014 was $6.4 \%$, while the average sick leave rate within public healthcare was $9.1 \%$ in 2014 (SSB 2015), making this an interesting sector to study. The sections of home care, assisted living and mental healthcare were chosen because these sections have good digital registers on personnel data, including all sickness absence of their employees.

The main finding of the paper is that there is an association between attitudes and sickness absences but mainly for self-certified sick leave. The only attitude variable associated with GP-certified sick leave is low work satisfaction, which is associated with higher GP-certified sick leave.

The level of sickness absence varies between different demographic groups (Allebeck and Mastekaasa 2004; Markussen et al. 2011). Perhaps most studied is the large difference in sickness absence observed between men and women. Additionally, other demographic characteristics, such as age, the level of education, the sector of work and the average number of working hours, have been found to be associated with specific attitudes towards sickness absence (Holmås and et al 2008). The data in this paper enables us to study whether attitudes can explain some of the observed variation in sickness absence between demographic groups, focusing on gaps in absenteeism between men and women, between younger and older employees, between those with lower and higher education and between immigrants and those born in the country of residence. In general, we do not find that attitudes are able to explain the observed differences in sickness absence between 
demographic groups. There is, however, some indication that attitudes can explain parts of the difference in self-certified sickness absence between employees with high and low education.

The paper is organised as follows: Section 2 provides details about the observed variations in sickness absence between demographic groups and the Norwegian sickness insurance system. Section 3 describes our questionnaire about attitudes towards sickness absence, the data and our empirical strategy. In Section 4, we present the results, and Section 5 concludes the study.

\section{Background}

\subsection{Variations in sickness absence between demographic groups}

Generally, women claim more sickness absence than men (Thorsen et al. 2015), and various explanations have been suggested and explored in the research literature. One factor that is found to be important is pregnancies. Myklebø (2007) find that as much as $60 \%$ of the gender gap in sickness absence is related to pregnancies. However, pregnancies do not seem to explain the entire gender gap.

Additional explanations for the gender gap in sickness absence which often are suggested are that women hold less healthy occupations and the double burden hypothesis, that employed women do a larger share of home- and childcare tasks than employed men. The results of studies investigating these mechanisms, however, are not conclusive. Mastekaasa and Dale-Olsen (2000), studying a representative population of Norwegian employees, find that the gender gap in sickness absence is not due to women being in less healthy jobs. A study of employees of the City of Helsinki, on the other hand, find that "Differences between occupations held by women and men explain a substantial part of the female excess in sickness absence" (Laaksonen and et al 2010, 394). Inconsistent results are also the case for studies of the double burden hypothesis. Bratberg et al. (2002) find support for the hypothesis, but Markussen and Strøm (2013) do not. Men and women have also been found to have different coping strategies, where women who experience being bullied at work have higher sickness absence, while men who experience the same are more likely to leave the labour force (Eriksen et al. 2016).

Despite considerable research on why women claim more sickness absence than men, our knowledge about the mechanisms behind the gender gap is still inadequate (NOU 2010:13 2010).

As is the case for gender, age is generally found to be a strong predictor of sickness absence behaviour (Allebeck and Mastekaasa 2004; Markussen et al. 2011). However, even though sickness absence generally increases with age, younger workers tend to be absent more frequently than older workers, who are associated with fewer, but longer, absence spells (Thomson et al. 2000; Alavinia et al. 2009). In line with this, Markussen et al. (2011) find that, up to the age of 45 , the probability of entering into a sickness absence spell declines sharply with age. They further argue that there might be two explanations for this relationship: either younger employees have a lower threshold for claiming sick than older employees or there are different norms regulating younger and older employees' absence.

Socioeconomic status is also an important determinant of sickness absence, with a negative association between the two (Allebeck and Mastekaasa 2004; Markussen et al. 2011; Piha and et al 2010). A part of this relationship is explained by unhealthy behaviour by those with lower socioeconomic status, such as smoking and inactivity (Allebeck and 
Mastekaasa 2004; Christensen et al. 2008; Thorsen et al. 2015). Markussen et al. (2011) find that educational attainment reduces the entry into sick leave but that it is the level of education, and not its type, that is relevant.

Holmås and et al (2008) analyse attitudes towards sickness absence in the Nordic countries. They find that women seem to be more restrictive than men in what they consider to be acceptable reasons for calling in sick. The same finding applies to older compared to younger employees: older employees seem to be more restrictive towards sickness absence than younger employees. When comparing employees with high education to those with lower education, Holmås and et al (2008) get ambiguous results, with higher educated employees being more restrictive towards some causes of sickness absence but less restrictive towards other causes.

There is a rising concern that increased immigration will cause a deterioration of extensive welfare programmes, because more heterogeneity in the population might weaken norms and support for such programmes (Bay et al. 2007). We study whether relevant attitudes can explain some of the observed variation in sickness absence between different demographic groups, focusing on gaps in absenteeism between men and women, between younger and older employees, between those with lower and higher education and between immigrants and those born in the country of residence.

\subsection{The Norwegian sickness insurance system}

Norway has a universal sickness insurance system including all employees, where the wage is normally $100 \%$ compensated from the first day of sickness and up to a year. The first 16 days of an absence spell is covered by the employer. After that, the expenses are paid by the Norwegian Labour and Welfare Service (NAV).

All employees are entitled to self-certified sick leave, meaning that the employee can notify the employer that he or she is unable to work due to illness or injury without having to present a medical certificate. Such self-certified sick leave can generally be used for up to three calendar days at a time. However, medical certification is not required until the ninth day for employees in firms participating in The Inclusive Workplace Agreement (IWA), known as the "IA agreement" in Norway, between employers, employees and the state. The population in this study is part of this agreement.

The employee must have been employed for at least two months to be entitled to selfcertified sick leave. Self-certified sick leave can be used four times in the course of a 12month period.

After the eighth calendar day of a sick leave spell, the employee must present a medical certificate from a general practitioner (GP). The GP evaluates the work capacity of the patient and issues the certificate if he or she finds sick leave necessary. If the employee is able to perform some work, graded (partial) sick leave is prescribed.

\section{Materials and methods}

\subsection{Data}

The data in this study were obtained from a paper-based questionnaire and linked to personnel data provided by the city of Oslo for the same sample. The survey was conducted in September and October 2014.

The questionnaire, a 12-page booklet, contained a cover page with the title, one page informing about the study and a statement of content, one page about how to fill 
out the questionnaire and ten pages consisting of 65 questions. The questionnaire was constructed to measure attitudes and norms related to sickness absence. The complete questionnaire can be found in the Additional file 1.

Personnel data was provided by the city of Oslo and contains information about the employee's contracts, position, department affiliation and shift plan. Furthermore, there is detailed information about the employee's sick leave: the start and end of each absence spell, type of absence, grading of sick leave and which department the employee was absent from. The data covers the period from 1 January 2013 to 1 October 2014. Descriptive statistics for all the variables used in the analysis is presented in Table 1.

\subsubsection{Procedures}

All employees within home care, assisted living and mental healthcare from two districts, District A and District B, within the city of Oslo were invited to a meeting within working hours. At these meetings, a representative from the research team informed the participants about the study. The employees were given the opportunity of answering the questionnaire during the meeting. Employees who were not on duty at the time of the meeting received a copy of the questionnaire and an envelope with pre-paid postage. Participants were told that the study was about sickness absence. The study was reported to the Data Protection Officer. Participants were informed about, and consented to, the city of Oslo providing information about them which would be matched with their answers to the questionnaire. It was emphasised that all information would be treated confidentially and that no individual answers would be given to the employer. Participants generally completed the questionnaire within 20 min.

\subsubsection{Sample and representativeness}

In total 284 public healthcare employees answered the questionnaire. Participants who handed in questionnaires lacking, or with errors in, the respondent's employee ID number were excluded from the study as they couldn't be matched with the employee register. On-call employees without a fixed number of working days were also excluded from the sample. This left us with a total sample of 226 employees and a response rate of 50.4\%. The final sample consists of $32 \%$ men and $68 \%$ women between 21 and 67 years of age, where the average age is 43 years. About $5 \%$ of the participants have primary education only, while $52 \%$ have education at the university level. The sample is ethnically diverse with around $27 \%$ with immigrant status. Almost $90 \%$ of the employees in our sample were employed throughout the whole period.

In order to be able to say something about the representativeness of our sample, the sample should be compared to the total population. District A provided us with necessary statistics for all employees within their district for 2014. If we concentrate on the subsample recruited from District A, our sample consists of $48.7 \%$ of the total number of employees in this district and $51 \%$ of the full-time equivalents. If this subsample was perfectly representative in terms of sick leave, we should expect to have around $51 \%$ of the employees' sick leave days in our sample. The actual number of self-certified sick leave days in this subsample is $52 \%$, which is just above the expected share. However, the share of GP-certified sick leave days is somewhat low (40\%). The reason might be that the employees having a sick leave spell during the period in which the survey was conducted, 
Table 1 Descriptive statistics

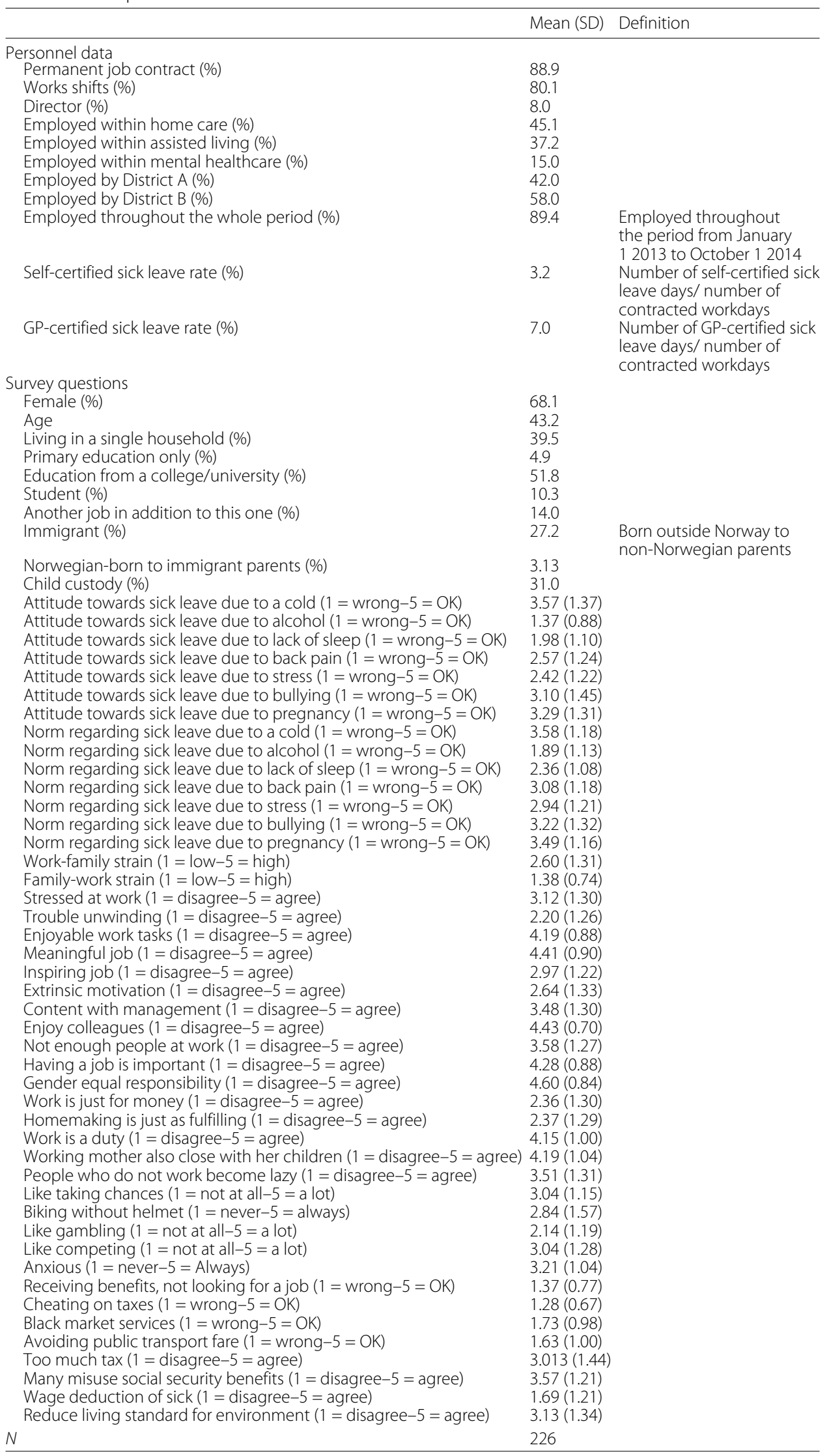


were harder to reach. Nevertheless, the questionnaires were sent home to those on longer sick leave spells, giving them a chance to participate.

\subsubsection{Survey questions}

The questionnaire included 45 questions attempting to measure attitudes, norms and preferences of potential importance to sickness absence. The entire questionnaire is provided in the Additional file 1.

The attitudes towards different justifications for being absent from work were measured with questions such as "What is your opinion regarding calling in sick (self-certified sickness absence) if one has not slept enough during the previous nights?" Answers were given on a 5 -point scale where 1 represented "Wrong" and 5 represented "OK". Answers with higher values thus represent more lenient attitudes towards sickness absence. The questions about attitudes towards different justification for being absent from work (question 1-7 in Table 2) were inspired by similar questions in Holmås and et al (2008) and Hansen and Andersen (2008).

The questionnaire included claims regarding more general attitudes towards work and work life, attitudes towards cheating or free-riding, attitudes towards gender equality and gender roles and attitudes towards social welfare benefits. The questions about work (questions 26-29) were inspired by the Norwegian Value Study (Holth 2010), and question 27 was also inspired by Hansen and Andersen (2008). The questions about cheating (questions 33-36) as well as gender roles (questions 30-32) were inspired by questions in the Norwegian Value Study (Holth 2010). The questions about social welfare benefits (questions 37-40) were our own.

Furthermore, the questionnaire included questions related to the social norms regarding sickness absence in the workplace (questions 8-14), measured by the respondents' beliefs concerning what attitudes most of their colleagues hold towards different justifications for being absent from work. These questions were our own.

Our questionnaire further included questions about stress and motivation. The questions about stress were inspired by the Norwegian Time Use Study (Rønning 2002) and Thomas and Ganster (1995) (questions 15 and 16), and Hansen and Andersen (2008) (questions 17 and 18). The questions about motivation included questions about intrinsic motivation (questions 19-21), taken from the Norwegian formulation used by Kuvaas and Dysvik (2009), and extrinsic motivation (question 22) used by Kuvaas and Dysvik (2011). In addition, there were questions about being content with one's work and managers (question 23), and whether the respondents enjoyed being around their colleagues (question 24), both inspired by Hansen and Andersen (2008).

Finally, the questionnaire included questions related to the employees' preferences and personality, as these aspects might be related to the propensity to report in sick. The three questions about risk preferences (questions 41-44) were inspired by the DOSPERT scale (Blais 2006), while the questions about competitive appetite (question 44) and anxiety (question 45) were our own. Table 1 presents the descriptive statistics for all variables.

\subsection{Variables}

\subsubsection{Sickness absence}

Our measures of sickness absence, self-certified sick leave and GP-certified sick leave are the rates of sick leave in percent of contracted working days. The rates are found 
Table 2 Construction of variables

\begin{tabular}{|c|c|c|}
\hline Variable & Question number & Questions \\
\hline & & $\begin{array}{l}\text { What is your opinion on calling in sick (self-certified } \\
\text { sickness absence)... }\end{array}$ \\
\hline & 1 & ...if one has a cold and a low-grade fever? \\
\hline & 2 & $\begin{array}{l}\text {...if one feels bad after drinking alcohol the } \\
\text { evening before? }\end{array}$ \\
\hline \multirow[t]{9}{*}{ 1: Lenient attitudes towards sick leave } & 3 & $\begin{array}{l}\text {...if one has not slept enough during the } \\
\text { previous nights? }\end{array}$ \\
\hline & 4 & ...if one has back pain when waking up in the morning? \\
\hline & 5 & ...if one feels unwell due to stress at work? \\
\hline & 6 & ...if one is being bullied at work? \\
\hline & 7 & ...if one is pregnant and feeling nauseous? \\
\hline & & $\begin{array}{l}\text { What do you think is the opinion of most others at your } \\
\text { work place } \\
\text { (your department) on calling in sick (self-certified } \\
\text { sickness absence)... }\end{array}$ \\
\hline & 8 & ...if one has a cold and a low-grade fever? \\
\hline & 9 & ...if one feels bad after drinking alcohol the \\
\hline & & evening before? \\
\hline \multirow[t]{7}{*}{ 2: Lenient norms regarding sick leave } & 10 & $\begin{array}{l}\text {...if one has not slept enough during the previous } \\
\text { nights? }\end{array}$ \\
\hline & 11 & $\begin{array}{l}\text {...if one has a sore back/back pain when waking up in } \\
\text { the morning? }\end{array}$ \\
\hline & 12 & ...if one feels unwell due to stress at work? \\
\hline & 13 & ...if one is being bullied at work? \\
\hline & 14 & ...if one is pregnant and feeling nauseous? \\
\hline & & Do you agree or disagree with the following statements? \\
\hline & 15 & $\begin{array}{l}\text { "I work so much at my job that I don't have enough } \\
\text { time for everything that needs to be done at home." }\end{array}$ \\
\hline \multirow[t]{5}{*}{ 3: Being stressed } & 16 & $\begin{array}{l}\text { "I have so much to do at home that I don't have } \\
\text { enough time for everything that needs to be done } \\
\text { at work." }\end{array}$ \\
\hline & 17 & "I often feel stressed at work." \\
\hline & 18 & "I do not manage to unwind/relax when I am off work." \\
\hline & & Do you agree or disagree with the following statements? \\
\hline & 19 & "The tasks that I do at work are enjoyable."”a \\
\hline \multirow[t]{5}{*}{ 4: Low motivation } & 20 & "My job is meaningful to me."a \\
\hline & 21 & $\begin{array}{l}\text { "Sometimes I become so inspired by my job that I } \\
\text { almost forget everything else around me." }\end{array}$ \\
\hline & 22 & $\begin{array}{l}\text { "If I am supposed to put in extra effort in my job, I need } \\
\text { to receive extra pay." }\end{array}$ \\
\hline & & Do you agree or disagree with the following statements? \\
\hline & 23 & $\begin{array}{l}\text { "I am content with the management at } \\
\text { my work place." }\end{array}$ \\
\hline \multirow[t]{4}{*}{ 5: Low work satisfaction } & 24 & "I enjoy being together with my colleagues." \\
\hline & 25 & "We are not enough people at work." \\
\hline & & Do you agree or disagree with the following statements? \\
\hline & 26 & "You need to have a job to have a good life." \\
\hline \multirow[t]{3}{*}{ 6: Low work ethic } & 27 & "Work is just a way of earning money." \\
\hline & 28 & "Work is a duty towards society." \\
\hline & 29 & "People who do not work become lazy."a \\
\hline
\end{tabular}


Table 2 Construction of variables (Continued)

\begin{tabular}{|c|c|c|}
\hline & & Do you agree or disagree with the following statements? \\
\hline \multirow{5}{*}{ 7: Gender equal attitudes } & 30 & "Men should take as much responsibility as women for their \\
\hline & & house and children." \\
\hline & 31 & "Being a homemaker is just as fulfilling as working for pay." \\
\hline & 32 & "A working mother can have an equally close and good \\
\hline & & relationship with her children as a mother who does not work." \\
\hline \multirow{5}{*}{ 8: Lenient towards cheating } & & What is your opinion on the actions below? \\
\hline & 33 & "Not looking for a job when receiving unemployment benefits." \\
\hline & 34 & "Cheating on taxes." \\
\hline & 35 & "Buying services on the black market." \\
\hline & 36 & "Avoiding a fare on public transport." \\
\hline \multirow{5}{*}{ 9: Negative towards welfare state } & & Do you agree or disagree with the following statements? \\
\hline & 37 & "We pay too much tax." \\
\hline & 38 & "Too many are misusing our social security benefits." \\
\hline & 39 & "Sickness absence should give a deduction from wage." \\
\hline & 40 & "I am willing to reduce my standard of living in order to save the environment." \\
\hline \multirow{5}{*}{ 10: Risk-averse preferences } & 41 & Do you like taking chances (risks)? ${ }^{a}$ \\
\hline & 42 & Do you bike without a helmet?a \\
\hline & 43 & Do you like gambling? ${ }^{a}$ \\
\hline & 44 & Do you like to compete? ${ }^{a}$ \\
\hline & 45 & Do you worry? \\
\hline
\end{tabular}

aThe Likert scale has been reversed

by dividing an employee's number of sick leave days in the period from 1 January 2013 to 1 October 2014, adjusted for possible grading of sick leave, by the total number of contracted working days for the employee in the same time period.

\subsubsection{Attitude variables}

From the questionnaire, we use 45 questions related to attitudes, norms and preferences. The answers to each of these questions have been standardised, so that the mean of each question is zero and the standard deviation is one. In order to reduce the number of variables in the regression analysis, we have, based on our own judgement, created attitude variables constructed of the sum of several question values. This results in ten attitude variables, which we have called Lenient attitudes towards sick leave, Lenient norms towards sick leave, Being stressed, Low motivation, Low work satisfaction, Low work ethic, Gender equal attitudes, Lenient towards cheating, Negative towards welfare state and Risk-averse preferences. Table 2 illustrates how the attitude variables have been constructed and which questions the variables are comprised of.

To make sure that the way we construct the attitude variables does not affect our results, a robustness test is presented in the Appendix where a factor analysis is used to group questions into variables. In this alternative procedure, we use an exploratory factor analysis to simplify the data set based on the correlations between the variables. The factor analysis results in five factors: Lenient sickness attitudes, Low intrinsic motivation, Lenient towards cheating, Being stressed and High homeload. For details about the factor analysis, and the results from it, see the Appendix. 


\subsubsection{Control variables}

The control variables include gender, immigrant status, a linear variable for education and age, a quadratic term for age and whether individual $i$ lives in a single household, has child custody, has more than one employer, is currently studying, is a director, holds a permanent position or works shift work. We also control for whether the employee works in assisted living or mental healthcare (compared to home care), and we control for district.

\subsection{The model}

We use regression model (1) to analyse the relation between attitudes and sickness absence, where $Y_{i}$ is the sick leave rate for individual $i, A_{i l}$ is the attitude of individual $i$ for attitude variable $l=1, \ldots, 10, X_{i k}$ is the control variables $k$ of individual $i K$ is the total number of control variables and $\varepsilon_{i}$ is the error term

$$
Y_{i}=\alpha_{0}+\sum_{l=1}^{10} \beta_{l} A_{i l}+\sum_{k=1}^{K} \gamma_{k} X_{i k}+\varepsilon_{i}
$$

The coefficients of interest are $\beta_{l}$ for each of the attitudes $l=1, \ldots, 10$. These coefficients will show the relationship between each attitude variable and sick leave. For instance, the interpretation of $\beta_{l}$ where $l$ for instance is Lenient attitudes towards sick leave is that increasing the leniency towards sick leave with one standard deviation is associated with an increase in the sick leave rate of the value of $\beta_{l}$.

The employees have contracts of various lengths. The information we have about sick leave is more accurate for those individuals that we observe over a longer period than for those we only observe for a week or two. We therefore include frequency weights in the regressions, so that the employees with longer contracts count more than those with shorter contracts. Mechanically, this means that the total number of observations, if we take the frequency weights into account, is 104,229. We use cluster robust standard errors to count for the serial correlation that occurs due to the frequency weights.

In order to investigate whether attitudes can explain some of the generally observed variation in sickness absence between different demographic groups, we use regression models (2)-(4). Models (2), (3) and (4) are essentially the same models as Model (1). However, we are now interested in contrasting the difference in sick leave between two dichotomous groups (men vs female, old vs young, high vs low educated and immigrants vs non-immigrants) and next see whether this difference can be explained by attitudes, that is whether significant differences in sickness absence vanishes or is reduced when the attitude variables are included in the model. If, for instance, the gender gap in sickness absence can be explained by women and men have different attitudes, then we should expect the coefficient on Female to be reduced in size and significance when attitudes are included in the model. By first excluding and then including the attitude variables in the regression, we can see how the coefficient on the various characteristics of interest changes. Because attitudes might affect self-certified sick leave and sick leave certified by a GP differently, we run the regression separately for the two outcomes.

In Model (2) we now want to focus on two demographic characteristics: Female and Immigrant. Whereas these two variables were included among the control variables in 
Model (1) (in the vector $X_{i k}$ ), they have been moved out in separate terms in Model (2).

$$
Y_{i}=\alpha_{0}+\alpha_{1} \text { Female }_{i}+\alpha_{2} \text { Immigrant }_{i}+\sum_{l=1}^{10} \beta_{l} A_{i l}+\sum_{k=3}^{K} \gamma_{k} X_{i k}+\varepsilon_{i}
$$

where $Y_{i}$ is the sick leave rate for individual $i$, Female ${ }_{i}$ and Immigrant $_{i}$ are dummy variables, $A_{i l}$ is the attitude of individual $i$ for attitude $l$ and $X_{i k}$ is the remaining control variables $k$ of individual $i$.

$$
Y_{i}=\alpha_{0}+\alpha_{3} \text { Low_education }_{i}+\sum_{l=1}^{10} \beta_{l} A_{i l}+\sum_{k=2}^{K} \gamma_{k} X_{i k}+\varepsilon_{i}
$$

In Model (3), we want to contrast employees with high and low education. While education is a linear variable with four educational levels in Models (1)-(2), in Model (3), Low education is a dummy variable taking the value of 1 for employees with no more than mandatory education and 0 otherwise.

$$
Y_{i}=\alpha_{0}+\alpha_{4} \operatorname{Old}_{i}+\sum_{l=1}^{10} \beta_{l} A_{i l}+\sum_{k=2}^{K} \gamma_{k} X_{i k}+\varepsilon_{i}
$$

In Model (4), we want to contrast young and old employees. While age was a continuous variable in Models (1)-(3), Model (4) includes the dummy variable Old, which takes the value 1 if the employee is in the oldest half of the sample and 0 otherwise. The continuous variable Age is excluded from this model. In this model, we use the categorical variable for education (as in Models (1) and (2)), and not the dummy variable Low education as in Model (3).

\section{Results}

In this section, we first present the results from Model (1) regarding the relationship between attitudes and sickness absence. Then we go on to present the results of Models (2), (3) and (4) on whether attitudes can explain the observed variation in sickness absence between different demographic groups.

As can be seen from Table 1, the self-certified sick leave rate is $3.2 \%$ on average, while the GP-certified sick leave rate is 7\%. The correlation coefficient between GP-certified sick leave and self-certified sick leave is, perhaps surprisingly, only 0.055 . The low correlation between the two sick leave variables is not due to there only being a few employees with GP-certified sick leave. Out of the 226 employees, there are 136 employees (60\%) who have GP-certified sick leave in the period we analyse, 168 employees (74\%) with selfcertified sick leave and 116 employees (51\%) with both self- and GP-certified sick leave. We do not find that the employees with a high level of GP-certified sick leave have a high level of self-certified sick leave or the other way around. It is therefore interesting to analyse the two sick leave variables separately.

\subsection{The relationship between attitudes and sickness absence}

The relationship between the attitude variables and sick leave (the results of Model (1)) is illustrated in Fig. 1. The figure shows the point estimates and the corresponding 90\% confidence intervals from regressions of self-certified sickness absence and GP-certified sickness absence on the attitude variables, when including all the control variables. If 


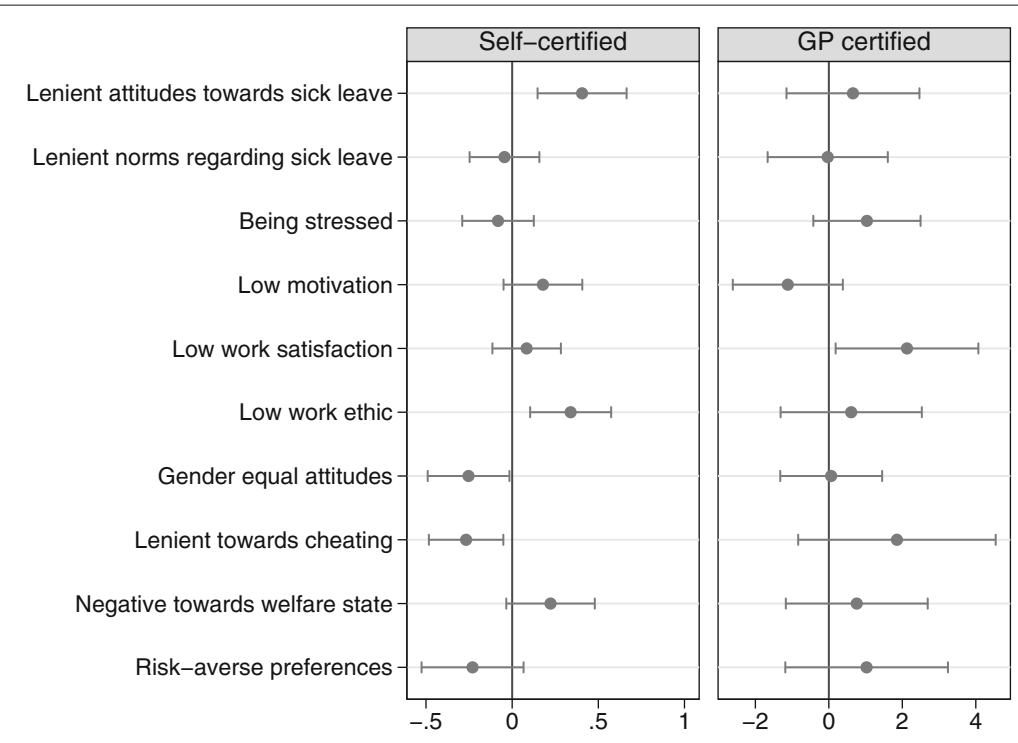

Fig. 1 Point estimates and 90\% confidence intervals for the attitude variables

the confidence interval overlaps the vertical line from zero, the attitude variable is not significantly different from zero.

Figure 1 reveals that there are four attitude variables with a significant relation to selfcertified sick leave: Lenient attitudes towards sick leave, Low work ethics, Gender equal attitudes and Lenient towards cheating. As expected, more lenient attitudes towards sickness absence and lower work ethics are associated with more self-certified sick leave, where a one-standard-deviation increase in Lenient attitudes towards sick leave is associated with a 0.4 percentage point increase in the self-certified sick leave rate. A one-standard-deviation increase in Low work ethics is associated with a 0.34 percentage point increase in the self-certified sick leave rate. Surprisingly, being more lenient towards cheating is associated with lower self-certified sick leave. An increase in Lenient towards cheating of one standard deviation is associated with a reduction in the self-certified sick leave rate of 0.27 percentage points. Likewise, a one-standard-deviation increase in reported gender equal attitudes is associated with a reduction in the self-certified sick leave rate of 0.25 percentage points.

When considering GP-certified sickness absence, only Low work satisfaction is significantly different from zero. Lower work satisfaction goes together with more GP-certified sick leave. Increasing Low work satisfaction with one standard deviation (which implies a reduction in work satisfaction) is associated with an increase in the GP-certified sick leave rate of 2.1 percentage points.

Only low work satisfaction is associated with GP-certified sickness absence. Additionally, looking at the $R$-squared in the upper panel of Table 5 reveals that the highest $R$-squared among the four specifications is for the model of self-certified sick leave where the attitude variables are included (specification (2)). Including the attitude variables in the model of self-certified sick leave gives a larger percentage increase in $R$-square (a $36 \%$ increase, from 0.157 to 0.214 ) relative to including the attitude variables in the model for GP-certified sick leave (a $32 \%$ increase, from 0.133 to 0.176 ). 
Taken together, we have seen that lenient attitudes towards sickness absence are related to self-certified sick leave, but not GP-certified sick leave. This is not surprising as the reasons for sickness absence which this variable is based on are most relevant for shortterm sickness absence (for instance, being absent from work due to a cold or due to having back pain when waking up in the morning). The results are supported by the robustness test presented in the Appendix, where all the analyses are repeated but where the variables are constructed using a factor analysis (for details about the factor analysis and the results of the robustness test analyses, see the Appendix).

\subsection{Can attitudes explain the observed variation in sickness absence between demographic groups?}

The results above suggest that attitudes might be able to explain some of the variation in sickness absence, in particular the variation in self-certified sick leave. Previous research has documented that the level of sickness absence varies substantially between different demographic groups. Specifically, the large difference in sickness absence between men and women has attracted a lot of attention. However, research has so far not managed to fully explain such differences in sickness absence. If attitudes should be able to explain parts of the sick leave gaps between men and women, old and young, employees with low and high levels of education and between immigrants and non-immigrants, there should also be attitude differences between these groups. And we find that there are indeed differences in our attitude variables between the groups of interest. Table 3 compares the reported attitudes for the four demographic groups.

We find no significant differences between men and women in their leniency towards sick leave. However, men in our sample score higher on low motivation and on low work ethic, implying that men have lower motivation and work ethic than women. Men also report lower gender equal attitudes and more lenient attitudes towards cheating than women. Furthermore, Table 4 shows that there are sickness absence differences across the demographic groups also in our sample, where women have on average more GP-certified sick leave than men.

To investigate whether attitudes can explain the difference in sick leave between men and women, we regress Model (2). The results from this regression is presented in the upper panel of Table 5, where self-certified sick leave is presented in column (1) and GPcertified sick leave in column (3). Secondly, we include our attitude variables in columns (2) and (4). If attitudes can explain some of the differences in sickness absence between men and women, the size of the coefficient on each of the dummy variables should be reduced when we control for attitudes related to sickness absence. We see from column (1) that there is no difference in self-certified sick leave between men and women. From column (2), we see that when we include attitudes in the model, the difference between men and women is still insignificant.

For GP-certified sick leave, there is a significant gap in sickness absence between men and women in our sample. When we further include attitudes in our regression, in column (4), we see that the coefficient on Female does not decrease. Actually the coefficient increases a little. This means that we find no evidence of attitudes being able to explain the gender gap in sickness absence.

Regarding immigrants compared to non-immigrants, we can see from Table 3 that immigrants in our sample are more stressed and report lower gender equal attitudes. We 


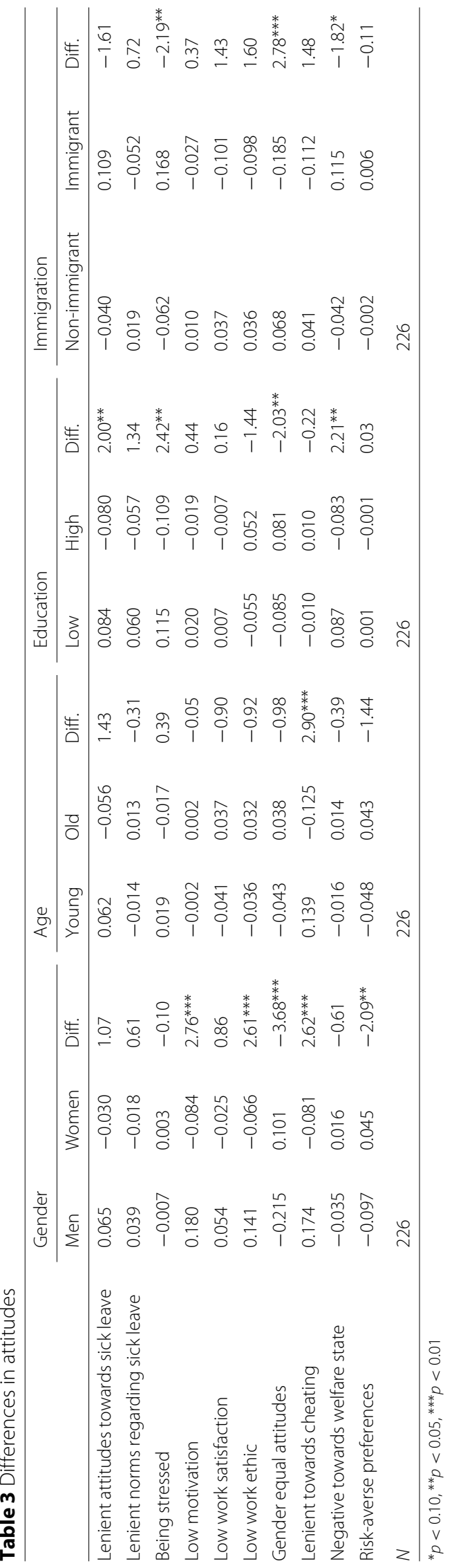


Table 4 Sickness absence among the groups of interest

\begin{tabular}{|c|c|c|c|c|c|c|c|c|}
\hline & Men & Women & Young & Old & $\begin{array}{l}\text { Low } \\
\text { education }\end{array}$ & $\begin{array}{l}\text { High } \\
\text { education }\end{array}$ & $\begin{array}{l}\text { Non- } \\
\text { immigrant }\end{array}$ & Immigrant \\
\hline & Mean & Mean & Mean & Mean & Mean & Mean & Mean & Mean \\
\hline Sick leave rate (\%) & 6.42 & 8.18 & 6.37 & 8.27 & 8.86 & 6.16 & 7.30 & 8.26 \\
\hline Self-certified sick leave rate (\%) & 1.55 & 1.24 & 1.43 & 1.29 & 1.57 & 1.09 & 1.34 & 1.36 \\
\hline GP-certified sick leave rate (\%) & 4.90 & 6.95 & 4.97 & 6.97 & 7.30 & 5.09 & 5.97 & 6.90 \\
\hline N & 72 & 154 & 107 & 119 & 110 & 116 & 165 & 61 \\
\hline
\end{tabular}

do not find any significant difference in sickness absence between immigrants and nonimmigrants in our sample. Furthermore, including the attitude variables does not change this fact. This result also holds if we separate the immigrants into continent of origin (results not shown).

When it comes to employees with different levels of education, and their attitudes, we find that employees with low education are more lenient towards sick leave and are more stressed than those with higher education. Those with higher education, on the other hand, report somewhat more gender equal attitudes and report being more positive to the welfare state. To investigate whether attitudes can explain the variation in sick leave between employees with high and low education, we regress Model (3). The results are presented in the middle panel of Table 5. Employees with low education have significantly more self-certified sick leave than employees with higher education, while there is no significant difference in GP-certified sick leave. When we control for attitudes in column (2), the coefficient on Low education reduces slightly. This might reflect that attitudes are part of the explanation of why employees with lower education have higher self-certified sickness absence than highly educated employees.

Comparing young and old employees, we see that younger employees in our sample are more lenient towards cheating. Regarding the relation between age and sick leave, it is not clear what to expect. Older workers are associated with fewer but longer spells of absence, while younger workers tend to be absent more frequently (Thomson et al. 2000; Alavinia et al. 2009). To study whether attitudes can explain the differences in sick leave between old and young employees, we regress Model (4). The results are presented in the bottom panel of Table 5. Table 5 shows that while the oldest half of our sample has a significantly higher GP-certified sick leave rate, there is no statistically significant difference in the selfcertified sick leave of young and old. Comparing the coefficient on Old in columns (3) and (4), we get the same effect as we did for Female: The coefficient on Old for GP-certified sick leave increases when controlling for attitudes. Despite having stricter attitudes, the older employees have more GP-certified sick leave than the younger. This might indicate that older employees would have had an even higher GP-certified sick leave rate, relative to younger employees, if attitudes were equalised across the two groups.

To explore the difference in self-certified sick leave between employees with high and low education further, we have performed a Blinder-Oaxaca decomposition. The Blinder-Oaxaca decomposition decomposes differences between groups to differences in endowments and coefficients. The results are presented in Table 6. Columns (1) and (2) show the results for self-certified sick leave. In column (1), all the control variables are used as explanatory variables, while in column (2), the attitude variables are included in addition as explanatory variables. The difference in self-certified sick leave between 
Table 5 Regression results

\begin{tabular}{|c|c|c|c|c|}
\hline & $\begin{array}{l}\text { (1) } \\
\text { Self-certified } \\
\text { coef. } \\
\text { (se) }\end{array}$ & $\begin{array}{l}\text { (2) } \\
\text { Self-certified } \\
\text { coef. } \\
\text { (se) }\end{array}$ & $\begin{array}{l}\text { (3) } \\
\text { GP certified } \\
\text { coef. } \\
\text { (se) }\end{array}$ & $\begin{array}{l}\text { (4) } \\
\text { GP certified } \\
\text { coef. } \\
\text { (se) }\end{array}$ \\
\hline Female & $\begin{array}{l}-0.311 \\
(0.19)\end{array}$ & $\begin{array}{l}-0.142 \\
(.018)\end{array}$ & $\begin{array}{l}2.330^{*} \\
(1.28)\end{array}$ & $\begin{array}{l}2.460^{*} \\
(1.48)\end{array}$ \\
\hline Immigrant & $\begin{array}{l}0.001 \\
(0.20)\end{array}$ & $\begin{array}{l}-0.096 \\
(0.21)\end{array}$ & $\begin{array}{l}0.736 \\
(1.25)\end{array}$ & $\begin{array}{l}1.087 \\
(1.30)\end{array}$ \\
\hline Lenient attitudes towards sick leave & & $\begin{array}{l}0.406^{* *} \\
(0.16)\end{array}$ & & $\begin{array}{l}0.657 \\
(1.10)\end{array}$ \\
\hline Lenient norms regarding sick leave & & $\begin{array}{l}-0.045 \\
(0.12)\end{array}$ & & $\begin{array}{l}-0.030 \\
(0.99)\end{array}$ \\
\hline Being stressed & & $\begin{array}{l}-0.082 \\
(0.13)\end{array}$ & & $\begin{array}{l}1.037 \\
(0.88)\end{array}$ \\
\hline Low motivation & & $\begin{array}{l}0.178 \\
(0.14)\end{array}$ & & $\begin{array}{l}-1.117 \\
(0.91)\end{array}$ \\
\hline Low work satisfaction & & $\begin{array}{l}0.084 \\
(0.12)\end{array}$ & & $\begin{array}{l}2.127^{*} \\
(1.18)\end{array}$ \\
\hline Low work ethic & & $\begin{array}{l}0.339^{* *} \\
(0.14)\end{array}$ & & $\begin{array}{l}0.609 \\
(1.16)\end{array}$ \\
\hline Gender equal attitudes & & $\begin{array}{l}-0.253^{*} \\
(0.14)\end{array}$ & & $\begin{array}{l}0.064 \\
(1.16)\end{array}$ \\
\hline Lenient towards cheating & & $\begin{array}{l}-0.267^{* *} \\
(0.13)\end{array}$ & & $\begin{array}{l}1.854 \\
(1.63)\end{array}$ \\
\hline Negative towards welfare state & & $\begin{array}{l}0.223 \\
(0.16)\end{array}$ & & $\begin{array}{l}0.760 \\
(1.17)\end{array}$ \\
\hline Risk-averse preferences & & $\begin{array}{l}-0.230 \\
(0.18)\end{array}$ & & $\begin{array}{l}1.028 \\
(1.34)\end{array}$ \\
\hline _cons & $5.402^{* * *}$ & $5.825^{* * *}$ & $18.001^{*}$ & $22.818^{* *}$ \\
\hline Controls ${ }^{a}$ & Yes & Yes & Yes & Yes \\
\hline Attitudes & No & Yes & No & Yes \\
\hline$R$-squared & 0.157 & 0.214 & 0.133 & 0.176 \\
\hline Low education & $\begin{array}{l}0.703^{* * *} \\
(0.22)\end{array}$ & $\begin{array}{l}0.674^{* * *} \\
(0.21)\end{array}$ & $\begin{array}{l}1.211 \\
(1.20)\end{array}$ & $\begin{array}{l}0.649 \\
(1.22)\end{array}$ \\
\hline Controls ${ }^{b}$ & Yes & Yes & Yes & Yes \\
\hline Attitudes & No & Yes & No & Yes \\
\hline$R$-squared & 0.154 & 0.213 & 0.135 & 0.176 \\
\hline Old & $\begin{array}{l}-0.075 \\
(0.22)\end{array}$ & $\begin{array}{l}-0.032 \\
(0.23)\end{array}$ & $\begin{array}{l}2.617^{*} \\
(1.37)\end{array}$ & $\begin{array}{l}2.776^{*} \\
(1.60)\end{array}$ \\
\hline Controls ${ }^{c}$ & Yes & Yes & Yes & Yes \\
\hline Attitudes & No & Yes & No & Yes \\
\hline$R$-squared & 0.141 & 0.194 & 0.107 & 0.140 \\
\hline$N^{d}$ & 226 & 226 & 226 & 226 \\
\hline
\end{tabular}

${ }^{*} p<0.10,{ }^{* *} p<0.05,{ }^{* * *} p<0.01$

a age, age ${ }^{2}$, education, na_educ, single_hh, na_singlehh, child_cust, na_custody, immig_sec, na_immig, student, secondjob, director, shifts, district_a, ass_living, mental_health

b female, age, age ${ }^{2}$, na_educ, single_hh, na_singlehh, child_cust, na_custody, immig_sec, immigrant, na_immig, student, secondjob, director, shifts, district_a, ass_living, mental_health

cfemale, education, na_educ, single_hh, na_singlehh, child_cust, na_custody, immig_sec, immigrant, na_immig, student, secondjob, director, shifts, district_a, ass_living, mental_health

dWe use frequency weights in the regressions due to the fact that we observe the employees for varying amounts of time, putting more weight on the employees that we have more information about. The frequency weights duplicate the observations according to the employees' number of working days. This means that the total number of observations, if we take the frequency weights into account, is 104,229 . We use cluster robust standard errors to count for the serial correlation that occurs due to the frequency weights 
Table 6 Results from Blinder-Oaxaco decomposition of difference in self-certified sickleave between employers with high and low education

\begin{tabular}{|c|c|c|}
\hline & $\begin{array}{l}\text { (1) } \\
\text { Self-certified } \\
\text { coef } \\
\text { (se) }\end{array}$ & $\begin{array}{l}\text { (2) } \\
\text { Self-certified } \\
\text { coef } \\
\text { (se) }\end{array}$ \\
\hline \multicolumn{3}{|l|}{ Overall } \\
\hline High education & $\begin{array}{l}1.089 * * * \\
(0.12)\end{array}$ & $\begin{array}{l}1.089^{* * *} \\
(0.12)\end{array}$ \\
\hline Low education & $\begin{array}{l}1.571^{* * *} \\
(0.13)\end{array}$ & $\begin{array}{l}1.571^{* * *} \\
(0.14)\end{array}$ \\
\hline Difference & $\begin{array}{l}-0.483^{* * *} \\
(0.18)\end{array}$ & $\begin{array}{l}-0.483^{* * *} \\
(0.18)\end{array}$ \\
\hline Endowments & $\begin{array}{l}0.425^{*} \\
(0.23)\end{array}$ & $\begin{array}{l}0.374 \\
(0.24)\end{array}$ \\
\hline Coefficients & $\begin{array}{l}-0.464^{* *} \\
(0.22)\end{array}$ & $\begin{array}{l}-0.327 \\
(0.21)\end{array}$ \\
\hline Interaction & $\begin{array}{l}-0.443^{*} \\
(0.26)\end{array}$ & $\begin{array}{l}-0.530^{* *} \\
(0.27)\end{array}$ \\
\hline \multicolumn{3}{|l|}{ Endowments } \\
\hline Female & $\begin{array}{l}0.011 \\
(0.02)\end{array}$ & $\begin{array}{l}0.001 \\
(0.01)\end{array}$ \\
\hline Age & $\begin{array}{l}2.006^{*} \\
(1.09)\end{array}$ & $\begin{array}{l}2.932^{* *} \\
(1.22)\end{array}$ \\
\hline $\mathrm{Age}^{2}$ & $\begin{array}{l}-1.656^{*} \\
(0.98)\end{array}$ & $\begin{array}{l}-2.493^{* *} \\
(1.11)\end{array}$ \\
\hline Immigrant & $\begin{array}{l}0.025 \\
(0.04)\end{array}$ & $\begin{array}{l}0.028 \\
(0.04)\end{array}$ \\
\hline \multicolumn{3}{|l|}{ Coefficients } \\
\hline Female & $\begin{array}{l}-0.124 \\
(0.28)\end{array}$ & $\begin{array}{l}-0.191 \\
(0.28)\end{array}$ \\
\hline Age & $\begin{array}{l}15.085 \\
(9.38)\end{array}$ & $\begin{array}{l}19.152^{* *} \\
(8.86)\end{array}$ \\
\hline $\mathrm{Age}^{2}$ & $\begin{array}{l}-7.604 \\
(5.29)\end{array}$ & $\begin{array}{l}-9.542^{*} \\
(4.95)\end{array}$ \\
\hline Immigrant & $\begin{array}{l}0.150 \\
(0.15)\end{array}$ & $\begin{array}{l}0.060 \\
(0.15)\end{array}$ \\
\hline _cons & $\begin{array}{l}-7.466^{*} \\
(4.14)\end{array}$ & $\begin{array}{l}-9.284^{* *} \\
(3.92)\end{array}$ \\
\hline \multicolumn{3}{|l|}{ Interaction } \\
\hline Female & $\begin{array}{l}0.008 \\
(0.02)\end{array}$ & $\begin{array}{l}0.013 \\
(0.03)\end{array}$ \\
\hline Age & $\begin{array}{l}-1.758 \\
(1.19)\end{array}$ & $\begin{array}{l}-2.232^{*} \\
(1.19)\end{array}$ \\
\hline $\mathrm{Age}^{2}$ & $\begin{array}{l}1.442 \\
(1.08)\end{array}$ & $\begin{array}{l}1.809^{*} \\
(1.07)\end{array}$ \\
\hline Immigrant & $\begin{array}{l}-0.051 \\
(0.06)\end{array}$ & $\begin{array}{l}-0.020 \\
(0.05)\end{array}$ \\
\hline Controls ${ }^{\mathrm{a}}$ & Yes & Yes \\
\hline Attitudes & No & Yes \\
\hline$N$ & 226 & 226 \\
\hline
\end{tabular}


employees with high and low education which we want to decompose is -0.483 , meaning that the low educated have higher sick leave than the high educated $(1.089-1.571=$ $-0.483)$. The reference group for the decomposition in Table 6 is employees with low education. The difference is decomposed into an explained part, which is due to differences in endowments or explanatory variables (labelled "endowments" in the table), and an unexplained part, which is due to different behavioural effects or coefficients between the two groups (labelled "coefficients" in the table) and an interaction effect between the endowment and coefficient effects. If low educated employees had the same endowments, that is if they had the same composition of background conditions (gender, age, type of jobs, etc.) as the high educated, the model estimates that they would have had even higher self-certified sick leave. At first sight, this might seem a bit surprising. In our sample, the low educated on average are older than the high educated. This might reflect that in for instance home care, the requirements for education has increased over time. Also, the highest self-certified sick leave in our sample is among the young and low educated. The endowment effect can be interpreted as how much self-certified sick leave the low educated would have if the group had the same age profile (and other characteristics) as the high educated, and the coefficient (or slope) of the low educated group. The coefficient effect, on the other hand, is the difference in self-certified sick leave estimated if the low educated had their own characteristics but the coefficients of the high educated. The model estimates that if the low educated had their own characteristics, but the coefficients of the high educated, their self-certified sick leave would have been significantly lower. The interaction effect is also negative, upweighing the increase in sick leave which was predicted by the endowment effect.

If attitudes are important for self-certified sick leave, this would be captured in the coefficient effect. From this Blinder-Oaxaca decomposition in specification (1), both the endowment effect and the coefficient effect are significant and the coefficient effect slightly larger. The results from the Blinder-Oaxaca decomposition in specification (1) thus supports our result that attitudes are relevant for explaining the difference in selfcertified sick leave between those with high and low education. From specification (2), we see that when including the attitude variables in the Blinder-Oaxaca decomposition, the endowment effect and coefficient effect no longer are significant. When including the attitude variables in the decomposition analysis, our measures of attitudes are moved from the coefficients into the endowment effect. While we know from specification (1) that the model predicts that self-certified sick leave would go up if the low educated had the characteristics of the high educated, it seems as though having the attitudes of the high educated would pull the sick leave of the low educated in the opposite direction, resulting in a non-significant effect.

To sum up, we find some evidence of attitudes being related to the higher selfcertified absence rate for employees with low education, relative to those with higher education. However, attitudes explain far from all of the differences in the self-certified sick leave rate between these two groups, and most of the differences in our sample remains unexplained. When considering gender and age, there are significant differences in GP-certified sick leave and there are significant differences in various attitudes between the groups. However, if we look more closely at these attitudes, we see that they are not the same variables as the ones we found actually having an association with GP-certified sick leave in Section 4.1. Therefore, it is perhaps not surprising that the 
attitude variables are not able to explain the gender and age differences in GP-certified sick leave.

\section{Conclusions}

In the present study, we examine the relation between attitudes and sickness absence. To study this, a survey aimed at identifying attitudes towards sick leave, work and cheating was conducted among employees within the public healthcare in Norway. The answers from the questionnaire were linked to detailed data on sickness absence, both selfcertified and GP-certified, gathered by the employer. The study is therefore based on a rather unique data set, as it combines objectively measured data on sick leave with self-reported attitudes, and includes data on both GP-certified and self-certified sick leave.

In general, one might expect employee attitudes to relate to self-certified sick leave to a greater extent than GP-certified sick leave, as self-certified sick leave is determined by the judgement of the employee alone. Nevertheless, whether an employee visits a doctor may be influenced by the employee's attitudes and preferences, as may the strength and power of the employees' arguments used towards the GP. Indeed, several previous studies have suggested that attitudes might be important for understanding the reasons behind the high levels of GP-certified sick leave (Allebeck and Mastekaasa 2004). We therefore have argued that in principle, attitudes towards sickness absence can be important for both self-certified and GP-certified sick leave and that this boils down to being an empirical question.

The first main result of our study is that several of the attitude variables are associated with sickness absence and mainly in the expected direction. It is especially interesting that the variable measuring attitudes towards reasons for sickness absence is associated with self-certified sick leave, but not GP-certified sick leave. This variable consists of questions constructed to capture attitudes towards short-term sickness absence, and it is precisely the self-certified and thus short-term absence where there is an association. Low work satisfaction, on the other hand, is a state which can be draining in the long run, and it is reasonable that this variable is associated with GP-certified sick leave. Summing up, it seems as though the attitude variables are most important for self-certified sick leave.

The second main result from our study is that attitudes generally are not able to explain the observed differences in sickness absence between demographic groups. For example, if attitudes towards sick leave should be able to explain the gender gap in sick leave, women should have more lenient attitudes towards sick leave than men. Although we find the commonly observed gender gap in GP-certified sick leave, we do not find a significant difference in attitudes towards sick leave between men and women. We do, however, find gender differences in some other attitude variables. In our sample, women have significantly higher motivation and work ethics than men, have more gender equal attitudes and are less lenient towards cheating than men. Nevertheless, the attitude variables were not able to reduce the observed gender gap in GP-certified sick leave. If anything, women would have had more sick leave had they had the same attitudes as men.

We do see an indication of attitudes being relevant for explaining why employees with lower education have higher self-certified sickness absence than those with higher education. However, controlling for attitudes in our regression only slightly reduces the 
difference between low and high education, and the difference in sick leave remains significant. We do not find any evidence of attitudes being important in explaining variation in GP-certified sickness absence between other demographic groups.

There are some concerns related to this study. First, one might be concerned that our sample is not large enough to estimate the relationship between attitudes and sickness absence precisely. Although this might be the case, we do find large variations in reported attitudes and we do reveal significant relationships. Also, the differences in sick leave within our demographic groups are as expected, although the gender difference in GP-certified sick leave is only significant at the $10 \%$ level. Furthermore, as discussed in Section 3.1, our sample seems to be fairly representative compared to the population under study.

A second concern might be the external validity of this study. The study was conducted among healthcare workers within home care, assisted living and mental healthcare. We know that there is a large fraction of women working in this field, and the sector might attract workers with certain attitudes, or certain attitudes might arise in such a sector. However, the public healthcare sector is a large employer in Norway. The results found in this study might thus be relevant, at least, for a relatively large part of the work force. Nevertheless, it is quite possible that one would find a larger variation in attitudes towards sickness absence with a sample from several different sectors and that this study underestimates the relation between attitudes and sickness absence. Future research should pursue studying attitudes across sectors.

Thirdly, we might not have been able to identify all relevant attitudes in our questionnaire. As there is a trade-off between including many questions and response rates, including additional questions comes at a cost. Although trying to keep the questionnaire as short as possible, the questionnaire includes the attitudes we considered most relevant.

One might also be concerned about whether the respondents have reported their attitudes truthfully. There is an assumption in economics that people will lie if it is to their material benefit. Evidence from lab experiments nevertheless suggest that people have an aversion towards lying even when lying gives a material benefit (Abeler et al. 2014; Fischbacher and Föllmi-Heusi 2013; Lundquist et al. 2009). This evidence, taken together with the fact that there is no material benefit from lying in the survey and that the survey is anonymous, makes us less worried about respondents not answering truthfully in the survey. If the inclination to lie varies systematically between the demographic groups of which we study, however, there might still be reason to worry. There does exist some evidence regarding lying aversion among men and women. If women had a lower aversion towards lying than men, it could be the case that the real attitudes of women were more lenient than that of men. However, as the evidence on the gender difference in lying if anything points towards women being less averse to lying than men (Childs 2012; Dreber and Johannesson 2008; Muehlheusser et al. 2015), we are more confident that lying does not confound our results.

Finally, this study is not able to distinguish between whether attitudes cause sick leave or whether sick leave causes certain attitudes. Nevertheless, an empirical study of the relation between attitudes and absence behaviour is an important first attempt, as a correlation between attitudes and sickness absence is a precondition for a causal relationship. 
In conclusion, this is the first paper studying the relationship between attitudes and sickness absence using objectively measured data on sickness absence. Previous studies have suggested that attitudes might be important for understanding variation in sickness absence. We find that there is an association between attitudes and sickness absence but mainly for self-certified sick leave. The results in our study do not support the notion that attitudes are able to explain differences in sickness absence between demographic groups.

\section{Appendix}

\section{Robustness test: analysis with attitude variables based on factor analysis}

In the main analysis, we have grouped the survey questions into attitude variables based on our own judgement. In this section, we perform an exploratory factor analysis to create the attitude variables. This is to make sure that the way we construct the attitude variables is not affecting our results.

\section{Factor analysis}

As in the main analysis, we want to reduce the number of questions from the questionnaire to a smaller number of variables describing attitudes and preferences. Factor analysis is used to uncover possible latent structures in the data, and we can therefore use it as a tool to group variables that pick up some of the same variation. We choose to perform an exploratory, as opposed to confirmatory, factor analysis because we do not want to assume anything about the relationship between the survey questions.

First, we keep the 38 main items from our questionnaire, describing attitudes, preferences and personality, and use the Kaiser-Meyer-Olkin measure to see if our data are suited for factor analysis. We find an overall value of 0.6237 , which is above the requirement of 0.5 (Frohlich and Westbrook 2001). Thereafter, we run a principal factor analysis with promax rotation. Promax rotation is chosen because we want to allow our factors to be correlated. The factors created are based on the eigenvalues of the covariance matrix of the standardised attitude variables and presented in the scree plot of the eigenvalues in Fig. 2. Based on the scree plot, we choose to keep five factors for the analysis. The

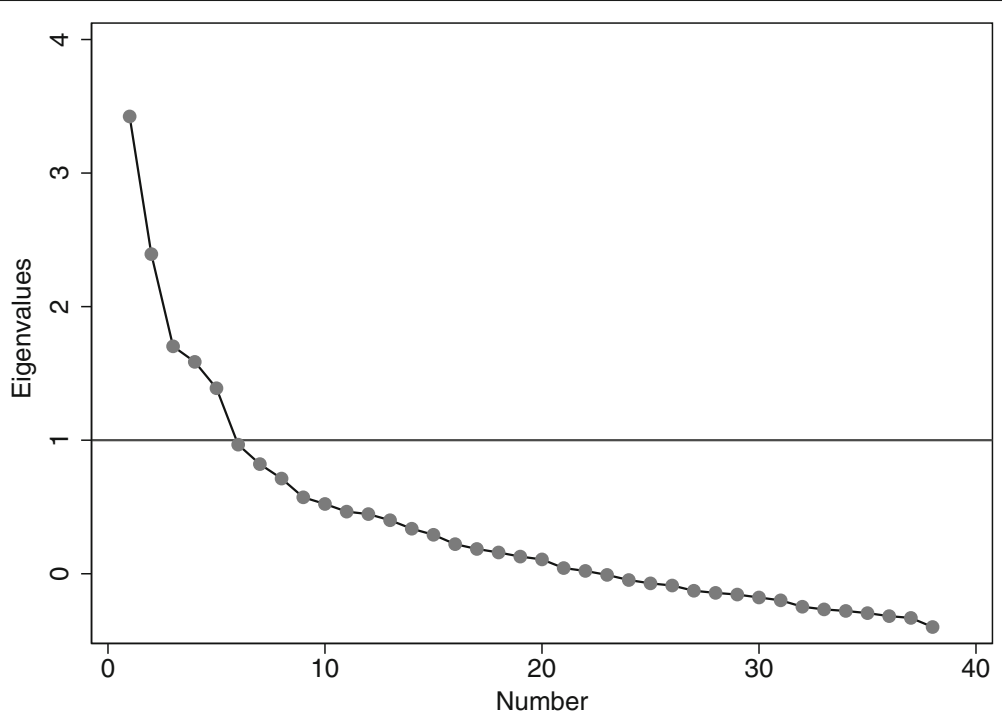

Fig. 2 Scree plot of the eigenvalues 


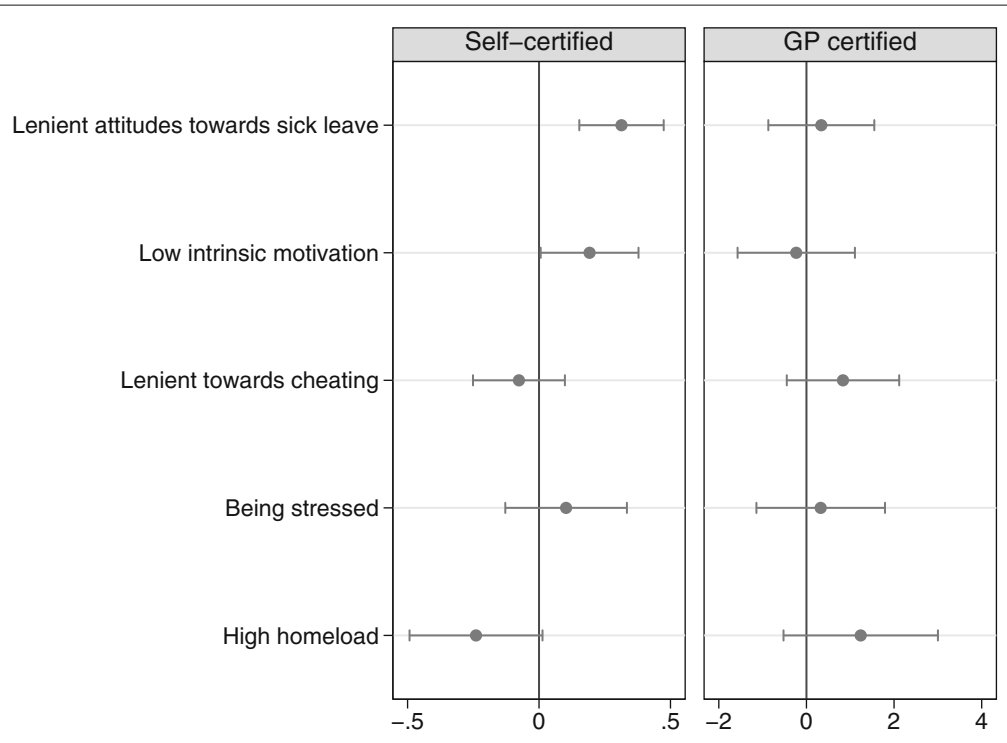

Fig. 3 Point estimates and 90\% confidence intervals for the attitude factors

eigenvalues measure the variance in the variables that are grouped into that factor, and only factors with eigenvalues above one are retained.

Table 7 shows the factors resulting from the factor analysis, together with the questions from the questionnaire with the highest loadings on this factor. The table also gives our a priori expectations of the factors' association with sickness absence. Factor loadings are the correlations between each variable and the factor. Loadings above 0.5 are characterised as large, moderate loadings are between 0.3 and 0.5 , and small loadings below 0.3 (Della Giusta et al. 2009). In Table 7, only loadings above 0.3 are shown, but all items loading on a factor are included when predicting the factors.

The direction of all the factors are such that the expected relation with sickness absence is positive; for instance, we expect that lenient attitudes towards self-caused sick leave cohere with more sick leave.

Comparing the variables created by the factor analysis in Table 7 with the variables presented in the main analysis (Table 2 in the main part of the paper), we see that the two sets of variables are quite similar. The factor analysis resulted in fewer factors than in the main analysis (five factors from the factor analysis compared to ten variables in the main analysis). The two sets of variables are, in substance, quite similar.

\section{Results from analysis using attitude factors}

In this section, we will repeat the analysis done in the main part of the paper, but instead of using the attitude variables from the main analysis, we will use the factors created by the factor analysis as variables in the regressions. As can be seen from Table 8, the factor Lenient attitudes towards sick leave is positive and significant for self-certified sick leave. None of the factors have a significant relation to GP-certified sick leave.

The coefficient of the variable Lenient towards sick leave was significant for self-certified sick leave also in the main analysis. In the main analysis, two additional variables were significant: Low work ethics and Lenient towards cheating. In the regressions based on 
Table 7 Factor analysis results

\begin{tabular}{|c|c|c|c|}
\hline \multirow[t]{2}{*}{ Factors } & \multicolumn{2}{|c|}{ Factor loadings Survey question } & \multirow{2}{*}{$\begin{array}{l}\text { A priori } \\
\text { expectation }\end{array}$} \\
\hline & & $\begin{array}{l}\text { What is your opinion on calling in sick (self-certified } \\
\text { sickness absence)... }\end{array}$ & \\
\hline & 0.4281 & ...if one has a cold and a low-grade fever? & \\
\hline & 0.4336 & $\begin{array}{l}\text {...if one has not slept enough during the previous } \\
\text { nights? }\end{array}$ & \\
\hline \multirow{6}{*}{$\begin{array}{l}\text { 1: Lenient attitudes towards } \\
\text { sick leave }\end{array}$} & 0.6520 & ...if one has back pain when waking up in the & \\
\hline & & morning? & + \\
\hline & 0.5753 & ...if one feels unwell due to stress at work? & \\
\hline & 0.4623 & ...if one is being bullied at work? & \\
\hline & 0.6526 & ...if one is pregnant and feeling nauseous? & \\
\hline & & $\begin{array}{l}\text { Do you agree or disagree with the following } \\
\text { statements? }\end{array}$ & \\
\hline \multirow[t]{4}{*}{ 2: Low intrinsic motivation } & 0.8151 & "The tasks that I do at work are enjoyable." a & + \\
\hline & 0.7646 & "My job job is meaningful to me."a & \\
\hline & & What is you opinion on the actions below? & \\
\hline & 0.7423 & "Cheating on taxes." & \\
\hline \multirow[t]{3}{*}{ 3: Lenient towards cheating } & 0.6202 & "Buying services on the black market." & + \\
\hline & 0.7217 & "Avoiding a fare on public transport." & \\
\hline & & $\begin{array}{l}\text { Do you agree or disagree with the following } \\
\text { statements? }\end{array}$ & \\
\hline \multirow[t]{3}{*}{ 4: Being stressed } & 0.8661 & "I often feel stressed at work." & + \\
\hline & 0.5185 & $\begin{array}{l}\text { "I do not manage to unwind/relax when I am } \\
\text { off work." }\end{array}$ & \\
\hline & & $\begin{array}{l}\text { Do you agree or disagree with the following } \\
\text { statements? }\end{array}$ & \\
\hline 5: High homeload & 0.6886 & $\begin{array}{l}\text { "I have so much to do at home that I don't have } \\
\text { enough time for everything that needs to be done } \\
\text { at work." }\end{array}$ & + \\
\hline
\end{tabular}

aThe Likert scale has been reversed

the factor analysis, Low work ethics is not included as a variable, while Lenient towards cheating is not significant. For GP-certified sick leave, there was one significant coefficient in the main analysis: Low work satisfaction. However, the factor analysis did not provide such a variable. Although some differences, the two methods of reducing the questions in the questionnaire to fewer variables give quite similar results. The variables created based on our own judgement are quite similar to those resulting from the factor analysis, and the regression results show qualitatively similar patterns.

The regression results in Table 8 show the same patterns as our main results. Women have significantly higher GP-certified sick leave rate than men, and including the attitude factors in the regression increases the Female coefficient, implying that attitudes cannot explain the higher sick leave rate among women. If anything, women would have had more sick leave had they had the same attitudes as men.

Employees with lower education have significantly higher self-certified sick leave rate than employees with higher education. As in the main analysis, adding the attitude factors reduces the difference in sickness absence between the two groups, implying that attitudes might explain some of the difference in sick leave between low and high educated employees. 
Table 8 Regression results using attitude variables based on factor analysis

\begin{tabular}{|c|c|c|c|c|}
\hline & $\begin{array}{l}\text { (1) } \\
\text { Self-certified } \\
\text { coef. } \\
\text { (se) }\end{array}$ & $\begin{array}{l}\text { ( } 2 \text { ) } \\
\text { Self-certified } \\
\text { coef. } \\
\text { (se) }\end{array}$ & $\begin{array}{l}\text { (3) } \\
\text { GP-certified } \\
\text { coef. } \\
\text { (se) }\end{array}$ & $\begin{array}{l}\text { (4) } \\
\text { GP-certified } \\
\text { coef. } \\
\text { (se) } \\
\end{array}$ \\
\hline \multirow[t]{2}{*}{ Female } & -0.311 & -0.219 & $2.330^{*}$ & $2.439^{*}$ \\
\hline & $(0.19)$ & $(.018)$ & $(1.28)$ & $(1.46)$ \\
\hline \multirow[t]{2}{*}{ Immigrant } & 0.001 & 0.020 & 0.736 & 0.302 \\
\hline & $(0.20)$ & $(0.19)$ & $(1.25)$ & $(1.30)$ \\
\hline \multirow[t]{2}{*}{ Factor 1: Lenient attitudes towards sick leave } & & $0.314^{* * *}$ & & 0.339 \\
\hline & & $(0.10)$ & & $(0.73)$ \\
\hline \multirow[t]{2}{*}{ Factor 2: Low intrinsic motivation } & & $0.192^{*}$ & & -0.232 \\
\hline & & $(0.11)$ & & $(0.81)$ \\
\hline \multirow[t]{2}{*}{ Factor 3: Lenient towards cheating } & & -0.076 & & 0.834 \\
\hline & & $(0.11)$ & & $(0.78)$ \\
\hline \multirow[t]{2}{*}{ Factor 4: Being stressed } & & 0.103 & & 0.326 \\
\hline & & $(0.14)$ & & $(0.89)$ \\
\hline \multirow[t]{2}{*}{ Factor 5: High homeload } & & -0.240 & & 1.239 \\
\hline & & $(0.15)$ & & $(1.07)$ \\
\hline _cons & $5.402^{* * *}$ & $5.918^{* * *}$ & $18.001^{*}$ & $18.920^{*}$ \\
\hline Controls ${ }^{a}$ & Yes & Yes & Yes & Yes \\
\hline Attitudes & No & Yes & No & Yes \\
\hline$R$-squared & 0.157 & 0.188 & 0.133 & 0.150 \\
\hline \multirow[t]{2}{*}{ Low education } & $0.703^{* * *}$ & $0.668^{* * *}$ & 1.211 & 0.642 \\
\hline & $(0.22)$ & $(0.21)$ & $(1.20)$ & (1.19) \\
\hline Controls $^{b}$ & Yes & Yes & Yes & Yes \\
\hline Attitudes & No & Yes & No & Yes \\
\hline$R$-squared & 0.154 & 0.184 & 0.135 & 0.150 \\
\hline \multirow[t]{2}{*}{ Old } & -0.075 & 0.046 & $2.617^{*}$ & $3.052^{*}$ \\
\hline & $(0.22)$ & $(0.23)$ & $(1.37)$ & $(1.58)$ \\
\hline Controls $^{c}$ & Yes & Yes & Yes & Yes \\
\hline Attitudes & No & Yes & No & Yes \\
\hline$R$-squared & 0.141 & 0.170 & 0.107 & 0.119 \\
\hline$N^{d}$ & 226 & 226 & 226 & 226 \\
\hline
\end{tabular}

${ }^{*} p<0.10,{ }^{* *} p<0.05,{ }^{* * *} p<0.01$

a age, age ${ }^{2}$, education, na_educ, single_hh, na_singlehh, child_cust, na_custody, immig_sec, na_immig, student, secondjob, director, shifts, district_a, ass_living, mental_health

bfemale, age, age ${ }^{2}$, na_educ, single_hh, na_singlehh, child_cust, na_custody, immig_sec, immigrant, na_immig, student, secondjob, director, shifts, district_a, ass_living, mental_health

cfemale, education, na_educ, single_hh, na_singlehh, child_cust, na_custody, immig_sec, immigrant, na_immig, student, secondjob, director, shifts, district_a, ass_living, mental_health

${ }^{d}$ We use frequency weights in the regressions due to the fact that we observe the employees for varying amounts of time, putting more weight on the employees that we have more information about. The frequency weights duplicate the observations according to the employees' number of working days. This means that the total number of observations, if we take the frequency weights into account, is 104,229 . We use cluster robust standard errors to count for the serial correlation that occurs due to the frequency weights

Older employees have significantly higher GP-certified sick leave rate than younger employees and equivalently as in the main analysis; including the attitude factors amplify this, again supporting the result from the main analysis.

Immigrants do not have significantly different sick leave than non-immigrants. 


\section{Additional file}

Additional file 1: Questionnaire. (PDF $775 \mathrm{~kb}$ )

\section{Acknowledgements}

Thanks to Knut Arne Hagtvet for advice regarding the factor analysis, to Simen Markussen and Oddbjørn Raaum for their suggestions and comments and to Michael Soukup for his help with the processing of data. All remaining errors remain the responsibility of the authors. We would also like to thank the editor for the useful comments.

Responsible editor: Juan Jimeno

\section{Funding}

The development and execution of the survey was financed by The Norwegian Ministry of Labour and Social Affairs. Data made available by the city of Oslo have been essential for the research project. This article is part of the project "Disentangling absence patterns", financed by the Norwegian Research Council (grant \#227103/H20), and the project "Work Life Challenges—workforce management and worker involvement solutions" (grant \# 202647/S20).

\section{Ethics approval and consent to participate}

The research project is reported to the Data Protection Official at the Frisch Centre. Since no sensitive data was used in the project, additional permission from the Norwegian Data Inspectorate was not required. The research is based on information collected through a survey and linked to information from administrative registers from the city of Oslo, with informed consent from all participants. The project complies with ethical standards set down in Norwegian law and overseen by the Norwegian Data Inspectorate.

\section{Competing interests}

The IZA Journal of Labor Policy is committed to the IZA Guiding Principles of Research Integrity. The authors declare that they have observed these principles.

\section{Publisher's Note}

Springer Nature remains neutral with regard to jurisdictional claims in published maps and institutional affiliations.

Received: 28 June 2017 Accepted: 25 August 2017

Published online: 11 October 2017

\section{References}

Abeler J, Becker A, Falk A (2014) Representative evidence on lying costs. J Public Econ 113:96-104

Alavinia SM, Van Den Berg TI, Van Duivenbooden C, Elders LA, Burdorf A (2009) Impact of work-related factors, lifestyle, and work ability on sickness absence among Dutch construction workers. Scand J Work Environ Health:325-333

Allebeck P, Mastekaasa A (2004) Chapter 5. Risk factors for sick leave—general studies. Scand J Public Health 32(63 suppl):49-108

Askildsen JE, Bratberg E, Nilsen ØA (2005) Unemployment, labor force composition and sickness absence: a panel data study. Health Econ 14(11):1087-1101

Bay A-H, Hellevik O, Hellevik T (2007) Svekker innvandring oppslutningen om velferdsstaten? Tidsskr Samfunnsforskning 48(3):377-408

Bjørnstad AF (2013) Utbetalingene av trygdeytelser siste 10 år. Arb og velferd 3:13-23

Blais A-R (2006) A domain-specific risk-taking (dospert) scale for adult populations. Judgment Decis Making 1(1):33-47

Bratberg E, Dahl S-Å, Risa AE (2002) 'The double burden': do combinations of career and family obligations increase sickness absence among women? Eur Sociol Rev 18(2):233-249

Childs J (2012) Gender differences in lying. Econ Lett 114(2):147-149

Christensen KB, Labriola M, Lund T, Kivimäki M (2008) Explaining the social gradient in long-term sickness absence: a prospective study of Danish employees. Journal of epidemiology and community health 62(2):181-183

Dale-Olsen H, Markussen S (2010) Økende sykefravær over tid? -Sykefravær, arbeid og trygd 1972-2008. Søkelys på arbeidslivet 27(01-02):105-121

Della Giusta M, Di Tommaso ML, Shima I, Strøm S (2009) What money buys: clients of street sex workers in the US Applied Economics 41(18):2261-2277

Dreber A, Johannesson M (2008) Gender differences in deception. Econ Lett 99(1):197-199

Eriksen TLM, Hogh A, Hansen ÅM (2016) Long-term consequences of workplace bullying on sickness absence. Labour Econ 43:129-150

European Commission (2016a) First preliminary outline of a European Pillar of Social Rights, Annex 1 of Launching a consultation on a European Pillar of Social Rights. Communication from the Commission to the European Parliament, the Council, the European Economic and Social Committee and the Committee of the Regions. SWD (2016) 51 final. Strasbourg, France

Spasova S, Bouget D, Vanhercke B (2016) Sick pay and sickness benefit schemes in the European Union, Background report for the Social Protection Committee's In-depth Review on sickness benefits. European Social Policy Network (ESPN), Brussels, European Commission

Fischbacher U, Föllmi-Heusi F (2013) Lies in disguise-an experimental study on cheating. J Eur Econ Assoc 11(3):525-547

Frohlich MT, Westbrook R (2001) Arcs of integration: an international study of supply chain strategies. J Oper Manag 19(2):185-200

Gran-Henriksen B (2014) Antall offentlige årsverk nesten tredoblet siden 1970, Statistics Norway. http://www.ssb.no/ offentlig-sektor/artikler-og-publikasjoner/offentlig-forvaltning-storrelse 
Hansen CD, Andersen JH (2008) Going ill to work-what personal circumstances, attitudes and work-related factors are associated with sickness presenteeism? Soc Sci Med 67(6):956-964

Hemp P (2004) Presenteeism: at work-but out of it. Harv Bus Rev 82(10):49-58

Henrekson M, Persson M (2004) The effects on sick leave of changes in the sickness insurance system. J Labor Econ 22(1):87-113

Holmås TH, et al (2008) Attitudes towards sickness absence in the nordic countries. Working Paper 18-2008. Stein Rokkan Centre for Social Studies. Bergen, Norway

Holth BA (2010) Verdiundersøkelsen 2008. Dokumentasjonsrapport. Notater 47/2010 Satistisk Norway. Oslo-Kongsvinger, Norway

Kuvaas B, Dysvik A (2009) Perceived investment in employee development, intrinsic motivation and work performance. Hum Resour Manag J 19(3):217-236

Kuvaas, B, Dysvik A (2011) Permanent employee investment and social exchange and psychological cooperative climate among temporary employees. Econ Ind Democr 32(2):261-283

Laaksonen M, et al (2010) Gender differences in sickness absence - the contribution of occupation and workplace. Scand J Work Environ Health 36(5):394-403

Lundquist T, Ellingsen T, Gribbe E, Johannesson M (2009) The aversion to lying. J Econ Behav Organ 70(1):81-92

Markussen S, Røed K, Røgeberg OJ, Gaure S (2011) The anatomy of absenteeism. J Health Econ 30(2):277-292

Markussen S, Strøm M (2013) The effects of motherhood, Memorandum, Department of Economics. University of Oslo, No. 19/2015

Mastekaasa A, Dale-Olsen H (2000) Do women or men have the less healthy jobs? An analysis of gender differences in sickness absence. Eur Sociol Rev 16(3):267-286

Muehlheusser G, Roider A, Wallmeier N (2015) Gender differences in honesty: groups versus individuals. Econ Lett $128: 25-29$

Myklebø S (2007) Sykefravær og svangerskap. Arbeid og velferd, Nr 3-2007:21-27. Arbeids- og velferdsdirektoratet

NOU 2010:13 (2010) Arbeid for helse. Sykefravær og utstøting i helse- og omsorgssektoren. Departementenes servicesenter Informasjonsforvaltning, Oslo

OECD (2010) Sickness, disability and work: breaking the barriers, A Synthesis of Findings across OECD Countries. OECD Publishing, Paris. http://dx.doi.org/10.1787/9789264088856-en

Piha K, et al (2010) Interrelationships between education, occupational class, income and sickness absence. Eur J Public Health 20(3):276-280. doi:https://doi.org/10.1093/eurpub/ckp162

Rønning E (2002) Statistisk sentralbyrås tidsbruksundersøkelse 2000/01. dokumentasjon og resultater fra intervjuet. Technical report

Scheil-Adlung X, Sandner L (2010) The case for paid sick leave. World Health Report Background Paper, 9

SSB (2015) Statistikkbanken: sykefravær. https://www.ssb.no/statistikkbanken/selecttable/hovedtabellHjem.asp? KortNavnWeb=sykefratot\&CMSSubjectArea=arbeidog-lonn\&checked=true. Accessed 17 July 2015

Thomas LT, Ganster DC (1995) Impact of family-supportive work variables on work-family conflict and strain: a control perspective. J Appl Psychol 80(1):6

Thomson L, Griffiths A, Davison S (2000) Employee absence, age and tenure: a study of nonlinear effects and trivariate models. Work Stress 14(1):16-34

Thorsen SV, Friborg C, Lundstrøm B, Kausto J, Örnelius K, Sundell T, Kalstø AM, Thune O, Gross B-O, Petersen H, Haram O (2015) Sickness in the Nordic Countries. Nord Soc Stat Comm 59:1-77

\section{Submit your manuscript to a SpringerOpen ${ }^{\circ}$ journal and benefit from:}

- Convenient online submission

- Rigorous peer review

- Open access: articles freely available online

- High visibility within the field

- Retaining the copyright to your article

Submit your next manuscript at $\boldsymbol{\triangleright}$ springeropen.com 